\title{
Modeling Parameter Selection Using A Random Generation Classification of Order Ten (10): Matlab Algorithm
}

\author{
Nwagor Peters*, Ojimba DP and Jim George Frimabo \\ Ignatius Ajuru university of Education Port Harcourt, Nigeria \\ *Corresponding author: Nwagor Peters, Ignatius Ajuru university of Education Port Harcourt, Nigeria
}

\begin{tabular}{|c|c|}
\hline ARTICLE INFO & ABSTRACT \\
\hline Received: 㓞 October 27, 2020 & \multirow{7}{*}{$\begin{array}{l}\text { Model parameter selection in the process of mathematical modeling is a formidable } \\
\text { problem which requires sophisticated algorithm indexed by a Matlab random generation } \\
\text { function having a dominant } 0.01 \text { intensity with very few instances of higher random } \\
\text { intensity for obvious reasons. This study have utilized the Matlab algorithm with } \\
\text { a random function of order ten (10) having the structure: } v=\mathrm{m}+0.01 \text { times rand(10) } \\
\text { with this random generation function. The novel result obtained shows boundary values } \\
\text { of each parameter estimate, and have proven clearly why we have chosen our present } \\
\text { model parameter values for the case of Port Harcourt HIV infection public health data } \\
\text { that defines the number of target cells, number of infected cells, and number of viral load } \\
\text { of the virions for every } 30 \text { day simplification for the purpose of HIV intervention strategy. }\end{array}$} \\
\hline Published: November 06, 2020 & \\
\hline \multirow{6}{*}{$\begin{array}{l}\text { Citation: Nwagor P, Ojimba DP, Jim George } \\
\text { F. Modeling Parameter Selection Using } \\
\text { A Random Generation Classification of } \\
\text { Order Ten (10): Matlab Algorithm. Biomed } \\
\text { J Sci \& Tech Res 31(4)-2020. BJSTR. } \\
\text { MS.ID.005145. }\end{array}$} & \\
\hline & \\
\hline & \\
\hline & \\
\hline & \\
\hline & $\begin{array}{l}\text { Keywords: Mathematical Modeling; Parameter Selection; Random Generation function; } \\
\text { Matlab Algorithm; Numerical simulation }\end{array}$ \\
\hline
\end{tabular}

\section{Introduction}

Parameter estimation problem being an integral aspect of mathematical modeling has been a long standing problem [1-3]. However, there is urgent need to specify one of the alternatives of determining the estimated parameter values with particular reference with the modeling of HIV infection of CD4+ T- cells. In fast developing country like Nigeria where public health data are in acute shortage for purpose of designing a database that can be useful in the intervention of HIV infection, it is worthwhile to implement and apply this present numerical approach for the purpose of a numerical characterization of a time dependent viral load of the virions with the insight of forming HIV infection intervention database for the city of Port Harcourt in Nigeria. The factors that define the depletion of viral load of the virions over time and those that increase the viral load over time can provide useful insight for the intervention of this public health concerns. Some of the challenging and salient businesses of modelers in mathematical immunology are to develop models, methods of analysis and control of the immune system processes [4-6]. Starting with the classic research of Nwagor P et al. [7-9], on immune system modeling and HIV-infection; this research in same vein also intends to examine further certain other properties of the already solved dynamic model which includes parameter estimation representing the HIV-infectio P n.

\section{Time Dependent ODE Model}

Following Nwagor (2020). A system of time dependent nonlinear first ordinary differential equations is considered. In the absence of the delay term with $\tau=0$ then the model reduces to

$$
\begin{aligned}
\frac{\mathrm{dT}}{\mathrm{dt}} & =S-\mathrm{dT}+\alpha T\left(1-\frac{T}{T_{\max }}\right)-\beta T V \\
\frac{d I}{d t} & =\beta T V-\delta I \\
\frac{\mathrm{dV}}{\mathrm{dt}} & =\rho I-c V
\end{aligned}
$$

Where the notations $\mathrm{T}$ represents the number of target cells, I represent the number of infected cells, $\mathrm{V}$ represents the viral load of the virions at time $t$ in units of days, $s$ represents the rate 
at which the new $\mathrm{T}$ cells are created from the source within the body such as the thymus, a represents the maximum proliferation rate of target cells. $\mathrm{T}_{\max }$ represents the $\mathrm{T}$ population density at which proliferation shuts off, $d$ represents the death rate of the $\mathrm{T}$ cells. $\beta$ represents the infection rate, $\delta$ represents the death rate of infective cells, $\rho$ represents the rate of cure, $c$ is the clearance rate constant of virions. The positive integer $\tau$ represents length of time measured in days. The system (1)-(3) satisfies the initial condition $T(0) \geq 0, I(0) \geq 0, V(0) \geq 0$

The possible non negative equilibrium of the system are $E_{1}\left(T^{o}, 0,0\right)$ and $E_{2}\left(T^{*}, I^{*}, V^{*}\right)$

Where $T^{O}=\frac{T_{\max }}{2 \alpha}\left[(\alpha-d) \pm \sqrt{(\alpha-d)^{2}+\frac{4 \alpha s}{T_{\max }}}\right] T^{*}=\frac{\partial c}{\beta \rho}$

$$
\begin{aligned}
& I^{*}=\frac{1}{\beta \rho}\left[\beta \rho-c d+\alpha c-\alpha \delta c^{2} / T_{\max }\right] \\
& V^{*}=\frac{1}{c \beta^{2} \delta T_{\max }}\left[\beta \rho-c d+\alpha c-\alpha \delta c^{2} / T_{\max }\right]
\end{aligned}
$$

And $R_{0}=\frac{T^{o}}{T^{*}}$

Where $R_{0}$ defines the basic reproductive ratio, which determines the dynamical property of the system $(1-3)$ over a long period of time.

\section{MATLAB Numerical Scheme}

The theory of MATLAB numerical scheme considered in this study involves the two-point boundary value problem of the equations of the form.

$$
\frac{d y}{d x}=f(x, y)
$$

Subject to the initial condition

$$
\frac{d y}{d x}=y\left(x_{o}\right)=y_{o}
$$

by increasing each step-in $\mathrm{x}$ by $\mathrm{h}$, so that the $\mathrm{n}^{\text {th }}$ step becomes

$$
x_{n}=x_{o}+n h
$$

The Euler algorithm for the determination of the approximation

$$
y_{n+1} \text { to } y\left(x_{n+1}\right) \text { is } y_{n+1}=y_{n}+f\left(x_{n}, y_{n}\right) h
$$

The modified Euler method involves taking the gradient of the tangent line approximation at $\left(x_{n}, y_{n}\right)$ the average of the gradient

$$
\left(x_{n}, y_{n}\right) \text { and }\left(x_{n+1}, y_{n+1}\right)
$$

so that the algorithm for the modified Euler for the determination of approximation is given by

$$
y_{n+1}=y_{n}+\frac{h}{2}\left[f\left(x_{n}, y_{n}\right)+f\left(x_{n}+h, y_{n}\right)+f\left(x_{n}, y_{n}\right) h\right]
$$

Also, the Runge-Kutta method which is based on a Taylor series approximation to the function $\mathrm{f}(\mathrm{x}, \mathrm{y})$ defines its algorithm for the determination of the approximation

$$
\begin{aligned}
& y_{n+1} \text { to } y\left(x_{n+1}\right) \text { as } \\
& y_{n+1}=y_{n}+\frac{1}{6}\left(k_{1}+2 k_{2}+2 k_{3}+k_{4}\right),
\end{aligned}
$$

Where

$$
\begin{aligned}
& k_{1}=h f\left(x_{n}, y_{n}\right) \\
& k_{2}=h f\left(x_{n}+\frac{1}{2} h, y_{n}+\frac{1}{2} k_{1}\right) \\
& k_{3}=h f\left(x_{n}+\frac{1}{2} h, y_{n}+\frac{1}{2} k_{2}\right) \\
& k_{4}=h f\left(x_{n}+\frac{1}{2} h, y_{n}+\frac{1}{2} k_{3}\right)
\end{aligned}
$$

The Runge-Kutta method also extends to the solution of the problem of the type

$$
\frac{d y}{d x}=f(x, y, z)
$$

And

$$
\frac{d z}{d x}=g(x, y, z)
$$

Subject to the initial conditions

$$
y\left(x_{o}\right)=y_{o} z\left(x_{o}\right)=z_{o}
$$

For a step of length $h$, and the nth integration step, the RungeKutta algorithm for systems is of the form

$$
y_{n+1}=y_{n}+\frac{1}{6}\left(k_{1}+2 k_{2}+2 k_{3}+k_{4}\right)
$$

And

$$
z_{n+1}=z_{n}+\frac{1}{6}\left(k_{1}+2 k_{2}+2 k_{3}+k_{4}\right)
$$

Where

$$
k_{1}=h f\left(x_{n}, y_{n}, z_{n}\right)
$$




$$
\begin{aligned}
& k_{2}=h f\left(x_{n}+\frac{1}{2} h, y_{n}+\frac{1}{2} k_{1}, z_{n}+\frac{1}{2} k_{1}\right) \\
& k_{2}=h f\left(x_{n}+\frac{1}{2} h, y_{n}+\frac{1}{2} k_{1}, z_{n}+\frac{1}{2} k_{2}\right) \\
& k_{3}=h f\left(x_{n}+\frac{1}{2} h, y_{n}+\frac{1}{2} k_{2}, z_{n}+\frac{1}{2} k_{2}\right) \\
& k_{4}=h g\left(x_{n+1}, y_{n}+k_{3}, z_{n}+k_{3}\right) \\
& \text { And } \\
& k_{1}=h g\left(x_{n}, y_{n}, z_{n}\right) \\
& k_{2}=h g\left(x_{n}+\frac{1}{2} h, y_{n}+\frac{1}{2} k_{1}, z_{n}+\frac{1}{2} k_{1}\right) \\
& k_{3}=h g\left(x_{n}+\frac{1}{2} h, y_{n}+\frac{1}{2} k_{1}, z_{n}+\frac{1}{2} k_{2}\right) \\
& k_{4}=h g\left(x_{n+1}, y_{n}+k_{3}, z_{n}+k_{3}\right)
\end{aligned}
$$

Hence, therefore the error (local) involved in the determination of $y_{n+1}$ from $y_{o}$ and $z_{n+1}$ from $z_{o}$ is $0\left(h^{5}\right)$ as with Runge-Kutta method. (Jeffery and Dai, 2006 in Nwagor 2019)

\section{Materials and Methods}

In this study, if $m$ represents a specified model parameter value that contributes to growth of targets cells, the growth of infected cells, and the growth of the viral load of the virions. We have utilized the following Matlab algorithm using a random function of order ten (10) having the following structure: $v=m+0.01$ times and(10) with this random generation function we are able to prove that the following that the following model parameter values of

$$
\begin{aligned}
& T_{\max }=1300, \beta=0.0002, \\
& \delta=0.5, \rho=1000, v=120, \\
& c=10, d=0.01, I=50, \alpha=6.8
\end{aligned}
$$

clearly satisfy a mathematical upper bound definition. This key assumption makes sense while the Port Harcourt HIV public health data should be considered as the best, minimum values in the context of modeling the characterization of a time dependent viral load of the virions.

\section{Results}

In The results of this study are presented as shown in Tables $1-10$.

Table 1: Parameter selection using Random generation function indexed by Matlab algorithm of order 10; scenario 1.

\begin{tabular}{|c|c|c|c|}
\hline Eg & Parameter & Parameter value & Random Parameter Value \\
\hline 1 & $\mathrm{~d}$ & 0.01 & 0.016238553056 \\
\hline 2 & $\delta$ & 0.5 & 0.504918262176 \\
\hline 3 & $\mathrm{c}$ & 10 & 10.00629268117 \\
\hline 4 & $\alpha$ & 6.8 & 6.803981847923 \\
\hline 5 & $\mathrm{~T}_{\max }$ & 1300 & 1340.752840693 \\
\hline 6 & $\mathrm{~s}$ & 5 & 5.005399158708 \\
\hline 7 & $\beta$ & 0.0002 & 0.007369622933 \\
\hline
\end{tabular}

Table 2: Parameter selection using Random generation function indexed by Matlab algorithm of order 10; scenario 2.

\begin{tabular}{|c|c|c|c|}
\hline Eg & Parameter & Parameter value & Random Parameter Value \\
\hline 1 & $\mathrm{~d}$ & 0.01 & 0.014878049132 \\
\hline 2 & $\delta$ & 0.5 & 0.504778347511 \\
\hline 3 & $\mathrm{c}$ & 10 & 10.00414556370 \\
\hline 4 & $\alpha$ & 6.8 & 6.803993470257 \\
\hline 5 & $\mathrm{~T}_{\max }$ & 1300 & 1353.616176786 \\
\hline 6 & $\mathrm{~s}$ & 5 & 5.005590781608 \\
\hline 7 & $\beta$ & 0.0002 & 0.007482744160 \\
\hline
\end{tabular}

Table 3: Parameter selection using Random generation function indexed by Matlab algorithm of order 10; scenario 3.

\begin{tabular}{|c|c|c|c|}
\hline Eg & Parameter & Parameter value & Random Parameter Value \\
\hline 1 & $\mathrm{~d}$ & 0.01 & 0.015783748452 \\
\hline 2 & $\delta$ & 0.5 & 0.503845233884 \\
\hline
\end{tabular}




\begin{tabular}{|c|c|c|c|}
\hline 3 & $\mathrm{c}$ & 10 & 10.00471427218 \\
\hline 4 & $\alpha$ & 6.8 & 6.805236992209 \\
\hline 5 & $\mathrm{~T}_{\max }$ & 1300 & 1355.180788041 \\
\hline 6 & $\mathrm{~s}$ & 5 & 5.005423792901 \\
\hline 8 & $\beta$ & 0.0002 & 0.004007139965 \\
\hline & $\rho$ & 1000 & 1093.825987542 \\
\hline
\end{tabular}

Table 4: Parameter selection using Random generation function indexed by Matlab algorithm of order 10; scenario 4.

\begin{tabular}{|c|c|c|c|}
\hline Eg & Parameter & Parameter value & Random Parameter Value \\
\hline 1 & $\mathrm{~d}$ & 0.01 & 0.016279884229 \\
\hline 2 & $\delta$ & 0.5 & 0.505121899926 \\
\hline 3 & $\mathrm{c}$ & 10 & 10.00510851985 \\
\hline 4 & $\alpha$ & 6.8 & 6.806035959270 \\
\hline 5 & $\mathrm{~T}_{\max }$ & 1300 & 1363.881851207 \\
\hline 6 & $\mathrm{~s}$ & 5 & 5.005766871935 \\
\hline 7 & $\beta$ & 0.0002 & 0.005100675264 \\
\hline 8 & $\rho$ & 1000 & 1039.122809121 \\
\hline
\end{tabular}

Table 5: Parameter selection using Random generation function indexed by Matlab algorithm of order 10; scenario 5.

\begin{tabular}{|c|c|c|c|}
\hline Eg & Parameter & Parameter value & Random Parameter Value \\
\hline 1 & $\mathrm{~d}$ & 0.01 & 0.015324483187 \\
\hline 2 & $\delta$ & 0.5 & 0.504625210898 \\
\hline 3 & $\mathrm{c}$ & 10 & 10.00363266988 \\
\hline 4 & $\alpha$ & 6.8 & 6.804740920781 \\
\hline 5 & $\mathrm{~T}_{\max }$ & 1300 & 1368.177281911 \\
\hline 6 & $\mathrm{~s}$ & 5 & 5.006936303499 \\
\hline 7 & $\beta$ & 0.0002 & 0.005931664864 \\
\hline 8 & $\rho$ & 1000 & 1085.199735721 \\
\hline
\end{tabular}

Table 6: Parameter selection using Random generation function indexed by Matlab algorithm of order 10; scenario 6.

\begin{tabular}{|c|c|c|c|}
\hline Eg & Parameter & Parameter value & Random Parameter Value \\
\hline 1 & $\mathrm{~d}$ & 0.01 & 0.015324483187 \\
\hline 2 & $\delta$ & 0.5 & 0.504625210898 \\
\hline 3 & $\mathrm{c}$ & 10 & 10.00363266988 \\
\hline 4 & $\alpha$ & 6.8 & 6.804740920781 \\
\hline 5 & $\mathrm{~T}_{\max }$ & 1300 & 1368.177281911 \\
\hline 6 & $\mathrm{~s}$ & 5 & 5.006936303499 \\
\hline 7 & $\beta$ & 0.0002 & 0.005931664864 \\
\hline 8 & $\rho$ & 1000 & 1085.199735721 \\
\hline
\end{tabular}

Table 7: Parameter selection using Random generation function indexed by Matlab algorithm of order 10; scenario 7.

\begin{tabular}{|c|c|c|c|}
\hline Eg & Parameter & Parameter value & Random Parameter Value \\
\hline 1 & $\mathrm{~d}$ & 0.01 & 0.015104488382 \\
\hline 2 & $\delta$ & 0.5 & 0.504287331791 \\
\hline 3 & $\mathrm{c}$ & 10 & 10.00709667600 \\
\hline 4 & $\alpha$ & 6.8 & 6.804872763926 \\
\hline 5 & $\mathrm{~T}_{\max }$ & 1300 & 1345.060622342 \\
\hline 6 & $\mathrm{~s}$ & 5 & 5.006164437469 \\
\hline 7 & $\beta$ & 0.0002 & 0.005851473248 \\
\hline 8 & $\rho$ & 1000 & 1029.343663474 \\
\hline
\end{tabular}


Table 8: Parameter selection using Random generation function indexed by Matlab algorithm of order 10; scenario 8.

\begin{tabular}{|c|c|c|c|}
\hline Eg & Parameter & Parameter value & Random Parameter Value \\
\hline 1 & $\mathrm{~d}$ & 0.01 & 0.014343716774 \\
\hline 2 & $\delta$ & 0.5 & 0.504289171699 \\
\hline 3 & $\mathrm{c}$ & 10 & 6.00465983788 \\
\hline 4 & $\alpha$ & 6.8 & 1344.425522022 \\
\hline 5 & $\mathrm{~T}_{\max }$ & 1300 & 5.005642880654 \\
\hline 6 & $\mathrm{~s}$ & 5 & 0.005473811254 \\
\hline 8 & $\beta$ & 0.0002 & 1097.530736270 \\
\hline
\end{tabular}

Table 9: Parameter selection using Random generation function indexed by Matlab algorithm of order 10; scenario 9.

\begin{tabular}{|c|c|c|c|}
\hline Eg & Parameter & Parameter value & Random Parameter Value \\
\hline 1 & $\mathrm{~d}$ & 0.01 & 0.012804635511 \\
\hline 2 & $\delta$ & 0.5 & 0.000504318283 \\
\hline 3 & $\mathrm{c}$ & 10 & 10.00648045724 \\
\hline 4 & $\alpha$ & 6.8 & 6.803993868287 \\
\hline 5 & $\mathrm{~T}_{\max }$ & 1300 & 1345.780558517 \\
\hline 6 & $\mathrm{~s}$ & 5 & 5.006202005058 \\
\hline 7 & $\beta$ & 0.0002 & 0.004443281469 \\
\hline 8 & $\rho$ & 1000 & 1090.546802208 \\
\hline
\end{tabular}

Table 10: Parameter selection using Random generation function indexed by Matlab algorithm of order 10; scenario 10.

\begin{tabular}{|c|c|c|c|}
\hline Eg & Parameter & Parameter value & Random Parameter Value \\
\hline 1 & $\mathrm{~d}$ & 0.01 & 0.013646065550 \\
\hline 2 & $\delta$ & 0.5 & 0.505131926954 \\
\hline 3 & $\mathrm{c}$ & 10 & 10.00570463411 \\
\hline 4 & $\alpha$ & 6.8 & 6.804496477385 \\
\hline 5 & $\mathrm{~T}_{\max }$ & 1300 & 1347.988191407 \\
\hline 6 & $\mathrm{~s}$ & 5 & 5.005020048792 \\
\hline 7 & $\beta$ & 0.0002 & 0.003759058161 \\
\hline 8 & $\rho$ & 1000 & 1038.028715741 \\
\hline
\end{tabular}

\section{Discussion of Results}

From Tables 1-10, it is observed that each model parameter value is strictly bounded above by its least upper bound which clearly shows that the choice of the model parameter values is the minimum for each range such as $0<\mathrm{m}<$ random parameter value, where $m$ specifies a model parameter value. This observation is consistent for Tables 1-10. However, results show that the value of $d$ ranges from 0.012804635511 to 0.016279884229 . The parameter value for $\delta$ ranges from 0.000504318283 to 0.505131926954 , whereas the parameter value for $\mathrm{c}$ ranging from 10.00363266988 to 10.00709667600 . More so, the parameter value of $\alpha$ lie between 6.803981847923 and 6.806035959270 . The parameter value Tma ranging 1340.752840693 to 1368.177281911 , while the value of $\mathrm{s}$ lye between 5.005020048792 and 5.006936303499 . The $\beta$ values ranges from 0.003759058161 to 0.007482744160 whereas the parameter value for $\rho$ has a minimum of 1029.343663474 and a maximum of 1097.530736270 .

\section{Conclusion and Further Research}

This study work have successfully utilized a Matlab function algorithm to conduct a systematic random generation of HIV infection model parameter values from which the choice of nonstochastic parameter values can be deduced as the minimum estimated values in this context. A future investigation will attempt to look at error analysis on the difference between pairs of such random generated data.

\section{References}

1. Culshaw Rebecca V, Shigui Ruan (2000) "A delay-differential equation model of HIV infectionof CD4 ${ }^{+}$T-cells." Mathematical Biosciences 165 (1): 27-39.

2. Ekaka a, EN Didia BC, Nwachukwu EC (2014) Parametric sensitivity analysis of a mathematical model of HIV infection of CD4+T-cells. Port Harcourt Medical Journal 8(1): 61-66.

3. Wester, Thomas, Daniel Isaac, Sonia Garcia (2015) Mathematical Modeling: Immune System Dynamics in the Presence of Cancer and 
Immunodeficiency in vivo." Working paper Department of Mathematics, United States Naval Academy, Annapolis.

4. Rihan Fathalla A, Duaa H Abdel Rahman (2013) Delay differentia model for tumor-immune dynamics with HIV infection of CD $4^{+}$T-cells." International Journal of Computer Mathematics 90 (3): 594-614.

5. Srivastava, Prashant, Peeyush Chandra (2008) "Modeling the dynamics of HIV and CD4+ T-cells during primary infection." Nonlinear Analysis: Real World Applications 10.

6. Truckwell Henry, Frederic Wan (2000) "Nature of equilibria and effects of drug treatments in some simple viral population dynamical models. IMA Journal of Mathematics Applied in Medicineand Biology 17: 311-27.

\section{ISSN: 2574-1241}

DOI: 10.26717/BJSTR.2020.31.005145

Nwagor Peters. Biomed J Sci \& Tech Res

(C) This work is licensed under Creative

Submission Link: https://biomedres.us/submit-manuscript.php
7. Nwagor P, Ekaka-a EN (2017) sensitivity of a mathematical model of HIV infection with a fractional order characterization. International Journal of Pure and Applied Sciences. Cambridge Research and Publications 10(1): 86-92.

8. Nwagor Peters (2020) Database Prediction of Co-existence and the Depletion of the Viral Load of the Virions of HIV Infection of CD4+ ${ }^{+}$T-cells. International Journal of Applied Science and Mathematics 7(1): 11-19.

9. Nwagor P (2019) Computational Characterisation of a Time Dependent Viral Load of the Virions in an HIV/AIDS Patient. PhD Thesis, RSU Nkpolu Orowurukwu Port Harcourt.

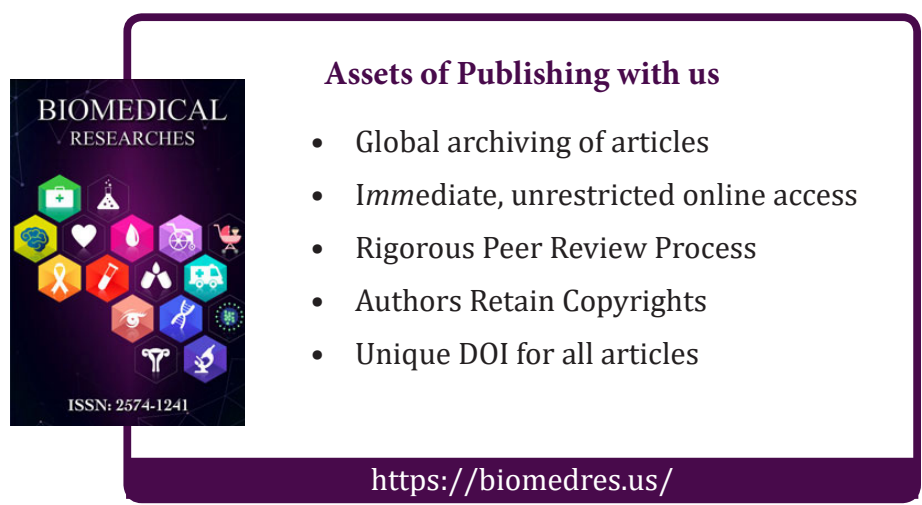

